\title{
Exploiting 1,2,3-Triazolium Ionic Liquids for Synthesis of Tryptanthrin and Chemoselective Extraction of Copper(II) Ions and Histidine-Containing Peptides
}

\author{
Hsin-Yi Li ${ }^{\dagger}$, Chien-Yuan Chen ${ }^{\dagger}$, Hui-Ting Cheng and Yen-Ho Chu ${ }^{*}$ \\ Department of Chemistry and Biochemistry, National Chung Cheng University, Chiayi 62102, Taiwan; \\ lanbarla0708@gmail.com (H.-Y.L.); passercloud@gmail.com (C.-Y.C.); coconuthead222@hotmail.com (H.-T.C.) \\ * Correspondence: cheyhc@ccu.edu.tw; Tel.: +86-5272-9139 \\ + Both authors contributed equally to this work. \\ Academic Editor: Hua Zhao \\ Received: 29 August 2016; Accepted: 9 October 2016; Published: 13 October 2016
}

\begin{abstract}
Based on a common structural core of 4,5,6,7-tetrahydro[1,2,3]triazolo[1,5-a]pyridine, a number of bicyclic triazolium ionic liquids $1-3$ were designed and successfully prepared. In our hands, this optimized synthesis of ionic liquids $\mathbf{1}$ and $\mathbf{2}$ requires no chromatographic separation. Also in this work, ionic liquids $\mathbf{1}, \mathbf{2}$ were shown to be efficient ionic solvents for fast synthesis of tryptanthrin natural product. Furthermore, a new affinity ionic liquid $\mathbf{3}$ was tailor-synthesized and displayed its effectiveness in chemoselective extraction of both $\mathrm{Cu}(\mathrm{II})$ ions and, for the first time, histidine-containing peptides.
\end{abstract}

Keywords: ionic liquid; Cu-free click reaction; tryptanthrin synthesis; affinity ionic liquid; copper ion; chemoselective extraction; peptide

\section{Introduction}

This paper describes the synthesis of bicyclic 1,2,3-triazolium ionic liquids 1-3 (Figure 1) [1], based on an intramolecular Hüisgen [3 + 2] cycloaddition (a Cu-free click reaction) [2,3], with specific aims to establish a common structural core for molecular diversity development of the ionic liquids and study their usefulness as reaction media for chemical synthesis and novel materials for biochemical applications. Ionic liquids are a class of polar solvents entirely made of ions, and many of them are liquids at room temperature $[4,5]$. Their ionic nature confers desirable properties to these liquids. They often possess wide liquid state ranges, high conductivity, excellent solubilization of many small molecules, good thermal stability, and negligible volatility [4,5]. The "green" character of ionic liquids largely refers to their very low vapor pressure, if any, and consequent inability to cause air pollution. Moreover, from the standpoint of organic synthesis, their blend of positive and negative charges makes these ionic liquids excellent microwave absorbers, giving rise to their recent emergence as superior alternatives to conventional molecular solvents for many microwave-assisted organic reactions [6].

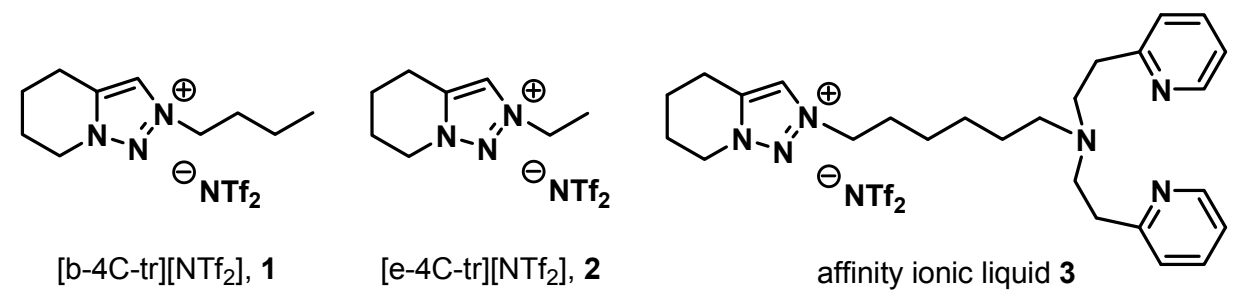

Figure 1. Structures of $[\mathrm{b}-4 \mathrm{C}-\mathrm{tr}]\left[\mathrm{NTf}_{2}\right]$ 1, [e-4C-tr] $\left[\mathrm{NTf}_{2}\right] 2$ and affinity ionic liquid 3. 
In our research, we are interested in developing new ionic liquids or improving the synthesis of known ionic liquids and we have an ongoing program to evaluate ionic liquids as stable media for chemical synthesis [7-11] and as functional materials for biochemical applications [12,13]. We recently reported the preparation of bicyclic 1,2,3-triazolium ionic liquids in four steps with good yields [1]. Because of their intriguing chemical stability and our continuing interest in conducting research with this class of ionic liquids, we decided to develop a more generalized synthesis so that these bicyclic ionic liquids could be explored and studied systematically.

\section{Results and Discussion}

Our synthesis of bicyclic 1,2,3-triazolium ionic liquids $\mathbf{1}, \mathbf{2}$ is illustrated in Scheme 1 . We aimed at demonstrating that these ionic liquids could be reliably prepared by a generalized synthetic route and therefore amended the previous synthesis by employing 5-hexyn-1-ol as the starting compound and successfully developed a 5-step synthesis of ionic liquids $\mathbf{1}$ and $\mathbf{2}$ in $93 \%$ overall isolated yield. First, the starting alcohol was mesylated using methanesulfonyl chloride in the presence of triethylamine at ambient temperature, followed by a two-step, one-pot reaction process involved in situ formation of 6-azidohex-1-yne using sodium azide and subsequently an intramolecular $\mathrm{Cu}$-free, Hüisgen $[3+2]$ cycloaddition in refluxing toluene for $6 \mathrm{~h}$ to afford the common 1,2,3-trazole core structure, 4,5,6,7-tetrahydro[1,2,3]triazolo[1,5-a]pyridine, with an excellent $98 \%$ isolated yield [14]. The progress of reactions could be readily monitored by TLC and, once reactions were complete, products were isolated and purified by straightforward extractions. The next reaction sequence proceeded with $N$-alkylation of the 1,2,3-triazole core by butyl methanesulfonate or ethyl methanesulfonate under heating conditions $\left(80^{\circ} \mathrm{C}\right.$ for $18 \mathrm{~h}$ and $73{ }^{\circ} \mathrm{C}$ for $10 \mathrm{~h}$, respectively) to cleanly produce the corresponding triazolium methanesulfonate salts, followed by metathesis with $\mathrm{LiNTf}_{2}$ in water at ambient temperature for $13 \mathrm{~h}$ to finally produce the desired ionic liquids $\mathbf{1}$ and $\mathbf{2}$ in excellent isolated yield (95\%, in two steps). The overall isolated yield for this 5-step synthesis of both [b-4C-tr][NTf 2$]$ (1) and [e-4C-tr] $\left[\mathrm{NTf}_{2}\right]$ (2) ionic liquids was 93\% (Scheme 1) [15]. Both ionic liquids obtained are liquids at room temperature. It is of note that this optimized synthesis of ionic liquids $\mathbf{1}$ and $\mathbf{2}$, in our hands required no chromatographic separation.
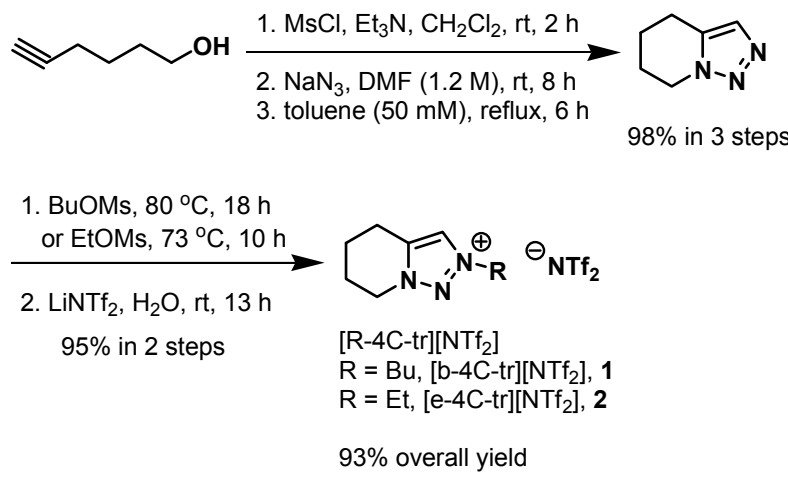

Scheme 1. Synthesis of bicyclic 1,2,3-triazolium ionic liquids 1 and 2.

We were interested in incorporating low-melting, hydrophobic $\left[\mathrm{NTf}_{2}\right]$ anion in $\mathbf{1}, \mathbf{2}$ primarily because of its water immiscibility, very low water content and low viscosity [4,5]. In addition, ionic liquids are known to be excellent microwave absorbers and thus should be useful for microwave-assisted organic synthesis. Accordingly, this high yielding preparation of ionic liquids allowed us to expediently investigate their applicability as ionic solvents for synthesis. In this work, we chose tryptanthrin as the target on which to investigate and support our design that synthesis of natural products could be promoted in ionic liquids [16].

Tryptanthrin is a biologically active quinazoline alkaloid isolated from a number of fungi (for instance Schizophyllum commune) and indigo plants (dried roots of Polygonum tinctorium, 
Isatis indigotica and Strobilanthes cusia) commonly known as "Ban Lan Gen" in Traditional Chinese Medicine [17,18]. In addition to its known antibacterial activity against various pathogenic microbes (e.g., Helicobacter pylori) and recently revealed antitubercular activity against Mycobacterium tuberculosis [19], tryptanthrin is a potent inhibitor of human cyclooxygenase 2 [20] and DNA topoisomerase I [21]. All these intriguing biological activities from tryptanthrin justify the study for its improved synthesis as a useful scaffold for drug discovery and the advanced development as anti-microbial, anti-inflammatory, and anti-neoplastic agents.

Many syntheses of tryptanthrin were reportedly achieved under basic and refluxing conditions (e.g., $\mathrm{Et}_{3} \mathrm{~N}$ in refluxing toluene for $16 \mathrm{~h}$ ) [19,22-30]. As one example, Srinivasan and co-workers reported the two steps synthesis of tryptanthrin in moderate $(54 \%)$ isolated yield involving the use of LDA and starting from anthranilic acid, methyl anthranilate, and ethyl orthoformate [26]. Although tryptanthrin could also be prepared by following the established Eguchi aza-Wittig reaction protocol, its overall isolated yield however was low (32\%) [31]. In the literature, the most common method for tryptanthrin synthesis is the reaction of isatoic anhydride with isatin in the presence of equimolar or excessive amounts of a base [17,18]. Scheme 2 illustrates our efficient microwaves-assisted synthesis of tryptanthrin carried out in ionic liquids 1 and 2.

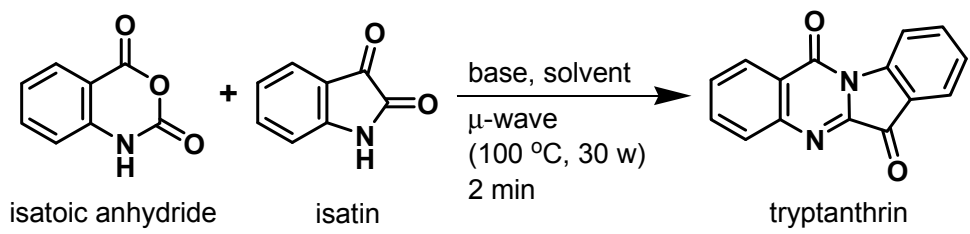

Scheme 2. Microwave-assisted synthesis of tryptanthrin in ionic liquids $\mathbf{1}$ and $\mathbf{2}$.

Table 1 summarizes our results obtained from the synthesis of tryptanthrin of which the middle two rings were concomitantly assembled from isatoic anhydride reaction with isatin in the presence or absence of base in both ionic ( $\mathbf{1}$ and $\mathbf{2}$ ) and common organic solvents (DMF and toluene). In this work, microwave irradiation was used to promote the double cyclization reactions and the polar, water-immiscible ionic liquids 1 or $\mathbf{2}$ were employed to deliberately drive the tryptanthrin-forming reaction to completion since water, once produced, was likely separated from the hydrophobic ionic liquid phase and rapidly evaporated under heating conditions. After several initial screenings of experimental conditions, it was quickly revealed that microwave irradiation (30 W) with the temperature controlled at $100{ }^{\circ} \mathrm{C}$ produced the best results.

Table 1. Synthesis of tryptanthrin in ionic $(\mathbf{1}, \mathbf{2})$ and molecular (DMF, toluene) solvents ${ }^{\mathrm{a}}$.

\begin{tabular}{cccc}
\hline Entry & Base & Solvent & Isolated Yield \\
\hline 1 & DIEA & ionic liquid 1 & $99 \%$ \\
2 & $\mathrm{Cs}_{2} \mathrm{CO}_{3}$ & ionic liquid 1 & $81 \%$ \\
3 & DIEA & ionic liquid 2 & $98 \%$ \\
4 & DIEA & DMF & $64 \%$ \\
5 & $\mathrm{Cs}_{2} \mathrm{CO}_{3}$ & DMF & $21 \%$ \\
6 & - & ionic liquid 1 & $19 \% \mathrm{~b}$ \\
7 & - & DMF & $6 \% \mathrm{~b}$ \\
8 & DIEA & toluene & no reaction \\
9 & $\mathrm{Cs}_{2} \mathrm{CO}_{3}$ & toluene & no reaction \\
\hline
\end{tabular}

a Experimental conditions: isatoic anhydride $(0.1 \mathrm{mmol})$, isatin $(0.1 \mathrm{mmol})$, base $(0.1 \mathrm{mmol})$, solvent $(50 \mu \mathrm{L})$, microwave at $100{ }^{\circ} \mathrm{C}(30 \mathrm{~W})$ for $2 \mathrm{~min} .{ }^{\mathrm{b}}$ condition: isatoic anhydride $(0.1 \mathrm{mmol})$, isatin $(0.1 \mathrm{mmol})$, solvent $(50 \mu \mathrm{L})$, microwave at $180^{\circ} \mathrm{C}(30 \mathrm{~W})$ for $10 \mathrm{~min}$.

It was found that with microwaves for a short $2 \mathrm{~min}$, the reaction of isatoic anhydride with isatin and the base $N, N$-diisopropylethylamine (DIEA) in ionic liquid $\mathbf{1}$ cleanly furnished the desired 
natural product tryptanthrin in quantitative isolated yield after chromatography (entry 1 , Table 1). An essentially identical yield (98\%) of tryptanthrin synthesis was obtained when performed in ionic liquid 2 (entry 3, Table 1).

In our hands, the reaction with the inorganic base $\mathrm{Cs}_{2} \mathrm{CO}_{3}$ in ionic liquid 1 gave a lower product yield (81\%, entry 2). When carried out in DMF, much lower isolated yields of tryptanthrin were obtained: $64 \%$ (with DIEA as base) and 21\% (with $\mathrm{Cs}_{2} \mathrm{CO}_{3}$ as base), respectively (entries 4 and 5 , Table 1). These results clearly demonstrated that ionic liquids $\mathbf{1}$ and $\mathbf{2}$ are excellent microwave absorbers, and these ionic solvents outperformed the molecular solvent DMF in the one-pot synthesis of tryptanthrin. Moreover, under our experimental conditions, toluene, a commonly used solvent for the synthesis of tryptanthrin, produced no trace of tryptanthrin (entries 8 and 9, Table 1) [19,22-30]. Although poor isolated yields of tryptanthrin were obtained in the ionic liquid 1 and DMF without the use of any base, ionic liquid 1 nevertheless produced a higher tryptanthrin yield than DMF: 19\% versus $6 \%$, respectively (entries 6 and 7, Table 1). This result obtained for the synthesis of tryptanthrin in ionic liquid 1 appears to be consistent with our recent report on the weak Lewis acidic nature of ionic liquids [32], which likely activates isatoic anhydride to facilitate tryptanthrin synthesis. Figure S1 (Supplementary Materials) illustrates a possible mechanism for the synthesis of tryptanthrin in ionic liquid without a base. Using thermogravimetric analysis (TGA), Figure S2 (Supplementary Materials) shows that both ionic liquids 1 and 2 have similar high temperature stability close to $400{ }^{\circ} \mathrm{C}$ (their thermal decomposition temperatures at $10 \%$ mass loss are $391{ }^{\circ} \mathrm{C}$ and $382{ }^{\circ} \mathrm{C}$, respectively), which are far above the optimized microwave heating temperature for tryptanthrin synthesis $\left(100{ }^{\circ} \mathrm{C}\right)$. These values are in good agreement with those reported for [ $\mathrm{NTf}_{2}$ ]-based ionic liquids [33].

The success of our general approach to triazolium ionic liquid synthesis and its application for a one-pot synthesis of the natural product tryptanthrin prompted us further to initiate a preliminary study to evaluate its use as affinity ionic liquid for both metal ions and peptides. Here, we chose copper(II) as our initial target ion so that its chemoselective extraction based on molecular recognition could be facilitated using an affinity ionic liquid 3 (AIL 3). The copper ion is abundant in human serum as well as the brain [34], and plays an important role as an endogenous regulator of neuronal activity in living systems [35,36] and is closely correlated with the pathogenesis of Alzheimer's disease [37]. Moreover, exposure to high copper concentrations can cause gastrointestinal disturbances, liver or kidney damage. Many fluorescence-based $\mathrm{Cu}(\mathrm{II})$ chemosensors have been reported and used for biological applications [38-40]. Scheme 3 illustrates our synthesis of affinity ionic liquid 3.
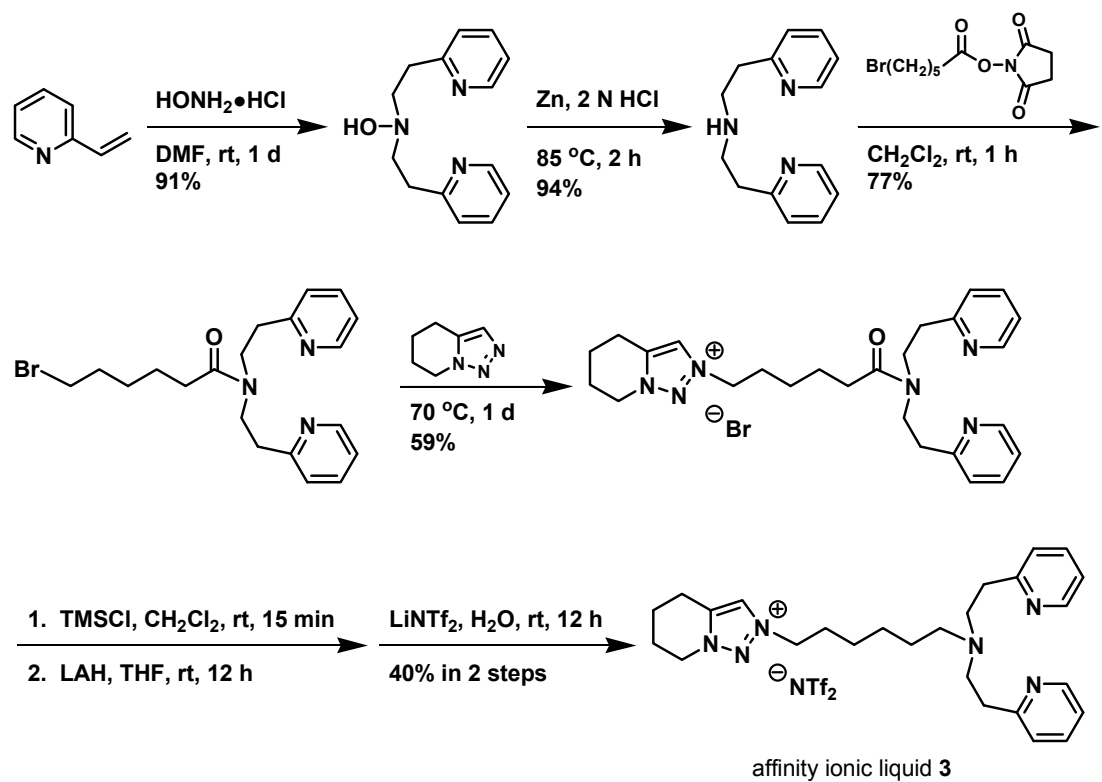

Scheme 3. Synthesis of affinity ionic liquid 3. 
Our synthesis of AIL 3 began with the Michael addition of hydroxylammonium chloride to 2-vinylpyridine in DMF at room temperature for $1 \mathrm{~d}$ (91\% yield), followed by a zinc reduction under acidic and heating conditions ( $94 \%$ yield) to afford the $\mathrm{Cu}(\mathrm{II})$-recognition element, N,N-bis(2-(2-pyridyl)ethyl)amine, as a pale yellow oil (85\% isolated yield in two steps) [41]. A straightforward amide bond coupling of the resulting bipyridylamine with $N$-succinimidyl 6-bromohexanoate was then carried out in dichloromethane at room temperature for $1 \mathrm{~h}$ (77\% yield) and, after that, the direct alkylation with the bicyclotriazole developed in this work at $70{ }^{\circ} \mathrm{C} \mathrm{for} 1 \mathrm{~d}$ (59\% yield), a LAH reduction at room temperature for $12 \mathrm{~h}$, and lastly an ion exchange in water at room temperature for $12 \mathrm{~h}$ (40\% yield in 2 steps) to ultimately obtain AIL 3. In our hands, the overall isolated yield in the AIL 3 synthesis was moderate: 16\% over a total of six steps starting from 2-vinylpyridine. This AIL 3 obtained is a viscous, pale yellow liquid at room temperature.

Results of both extraction photos and UV-vis spectra shown in Figure 2 unambiguously demonstrate that the AIL 3 dissolved in [e-4C-tr] $\left[\mathrm{NTf}_{2}\right]$ ionic liquid 2 chemoselectively recognized $\mathrm{Cu}(\mathrm{II})$ ion in water (the upper layer) and, as a result, effectively extracted it into the ionic liquid (bottom layer). In these affinity extraction experiments, equal volumes of ionic liquid and water were first mixed, the resulting mixtures were then vigorously shaken and lastly centrifuged all at ambient temperature to accomplish the extraction. As shown in Figure 2B,C, Co(II) and Ni(II) ions remained unaffected in the upper water layer upon extraction, indicating that the partitioning of Co(II) and $\mathrm{Ni}(\mathrm{II})$ into ionic liquid phase containing AIL 3 was negligible as demonstrated in their UV-vis spectra, and the recognition of AIL 3 toward $\mathrm{Cu}(\mathrm{II})$ is clearly chemospecific (Figure 2A).

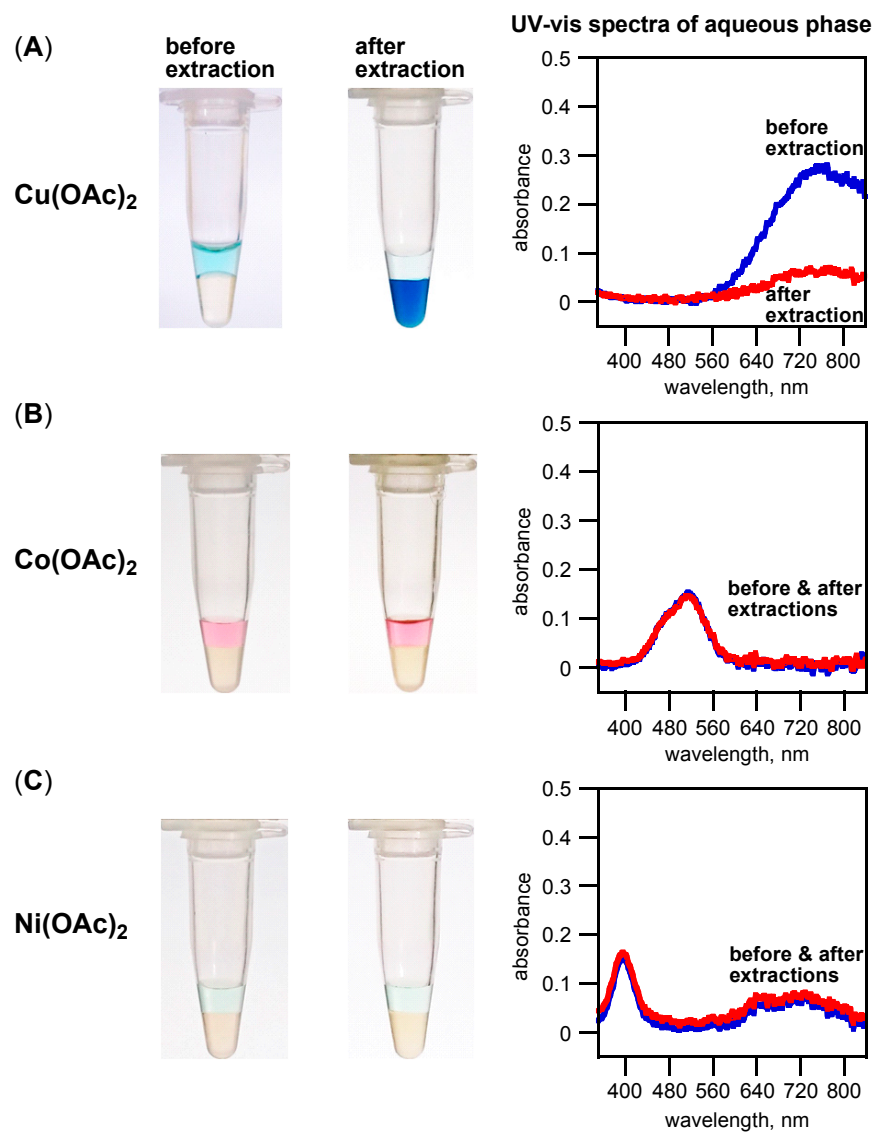

Figure 2. Optical photographic images and UV-vis spectra of chemoselective extractions of (A) $\mathrm{Cu}(\mathrm{OAc})_{2}(0.1 \mathrm{M}) ;(\mathbf{B}) \mathrm{Co}(\mathrm{OAc})_{2}(0.25 \mathrm{M})$ and $(\mathbf{C}) \mathrm{Ni}(\mathrm{OAc})_{2}(0.25 \mathrm{M})$ in $\mathrm{H}_{2} \mathrm{O}(25 \mu \mathrm{L}$ each) by AIL $3(0.25 \mathrm{M})$ in ionic liquid $2(25 \mu \mathrm{L})$, respectively. UV-vis spectra (1 mm path length) of aqueous layers were obtained by a NanoDrop 2000 spectrophotometer (Thermo Scientific, Waltham, MA, USA). 
Moreover, the affinity extraction experiment shown in Figure 3 further proved that, in the presence of both $\mathrm{Cu}(\mathrm{OAc})_{2}(0.1 \mathrm{M})$ and excessive $\mathrm{Co}(\mathrm{OAc})_{2}(0.5 \mathrm{M})$ in water, the complete transfer of only $\mathrm{Cu}(\mathrm{II})$ ion from the aqueous phase into the ionic liquid was entirely due to affinity recognition by AIL 3 $(1.0 \mathrm{M})$. This chemoselective extraction of $\mathrm{Cu}(\mathrm{II})$ ion and total retention of $\mathrm{Co}(\mathrm{II})$ were demonstrated in its UV-vis spectra and also apparent to the naked eyes (Figure 3).

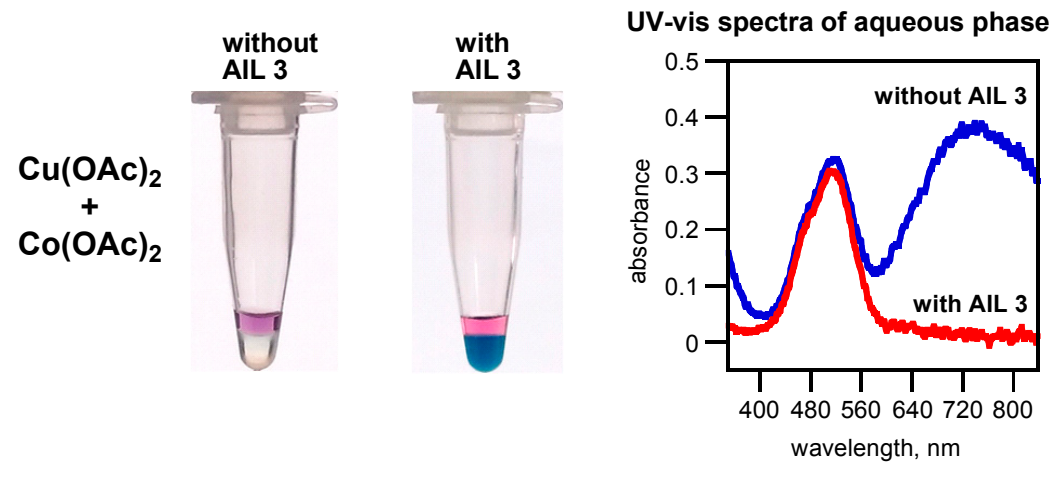

Figure 3. Optical photographic images and UV-vis spectra of affinity extraction of an aqueous solution $(10 \mu \mathrm{L})$ containing $\mathrm{Cu}(\mathrm{OAc})_{2}(0.1 \mathrm{M})$ and $\mathrm{Co}(\mathrm{OAc})_{2}(0.5 \mathrm{M})$ by AIL $3(1.0 \mathrm{M})$ in ionic liquid $2(10 \mu \mathrm{L})$.

To determine the stoichiometry of AIL 3-Cu(II) binding interaction, samples having a fixed concentration of an affinity ligand 4 (a surrogate of AIL 3) in DMSO/ $\mathrm{H}_{2} \mathrm{O}(5: 1, v / v$ ) solution and various concentrations of $\mathrm{Cu}(\mathrm{OTf})_{2}$ were prepared to perform affinity extractions. As depicted in Scheme 4 , affinity ligand 4 could be readily prepared with good $75 \%$ yield by a straightforward Michael addition of $n$-hexylamine to 2-vinylpyridine.
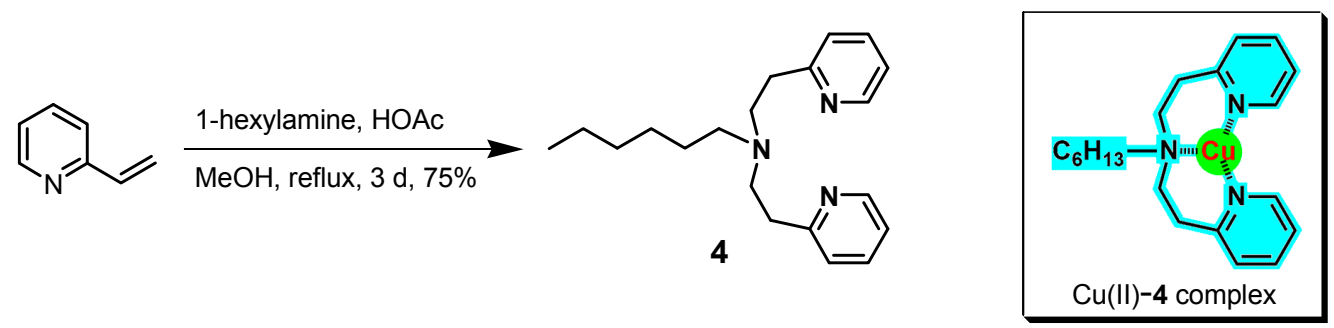

Scheme 4. Synthesis of affinity ligand 4 and the proposed structure of $\mathrm{Cu}(\mathrm{II})-4$ complex.

The results in Figure 4 show that as the ratio of $(\mathrm{Cu}(\mathrm{II})) /(4)$ increased, the concentration (i.e., absorbance at $680 \mathrm{~nm}$ ) of $4-\mathrm{Cu}(\mathrm{II})$ complex increased until the ratio reached its binding stoichiometry; beyond this value no more complex could be formed because all 4 has been fully titrated and associated with $\mathrm{Cu}$ (II) ion, and therefore excessive $\mathrm{Cu}$ (II) ion remained unbound in the solution (Figure $4 \mathrm{~A}$ ). This broad band having a $\lambda_{\max }$ at $680 \mathrm{~nm}$ with its growth in intensity was from the d-d transition of blue $\mathrm{Cu}$ (II) complex with affinity ligand 4 [38-40]. The plot of the $\mathrm{A}_{680 \mathrm{~nm}} \mathrm{vs}$. the ratio of $(\mathrm{Cu}(\mathrm{II})) /(4)$ revealed an abrupt change in the slope, corresponded to the binding stoichiometry of the system studied; that is, an expected 1:1 stoichiometry of this model 4-Cu(II) binding interaction was obtained (Figure 4B). It is likely that the 4-Cu(II) complex adopt a square-pyramidal coordination geometry in which affinity ligand 4 binds at the basal plane and two triflates occupy the remaining sites (Scheme 4) [41,42]. Overall, we were pleased that affinity ionic liquid 3 effectively dissolved and extracted $\mathrm{Cu}(\mathrm{II})$ into ionic liquid 2 , and its affinity ligand 4 tightly associated with $\mathrm{Cu}$ (II) to form a stable 1:1 complex. 
(A)

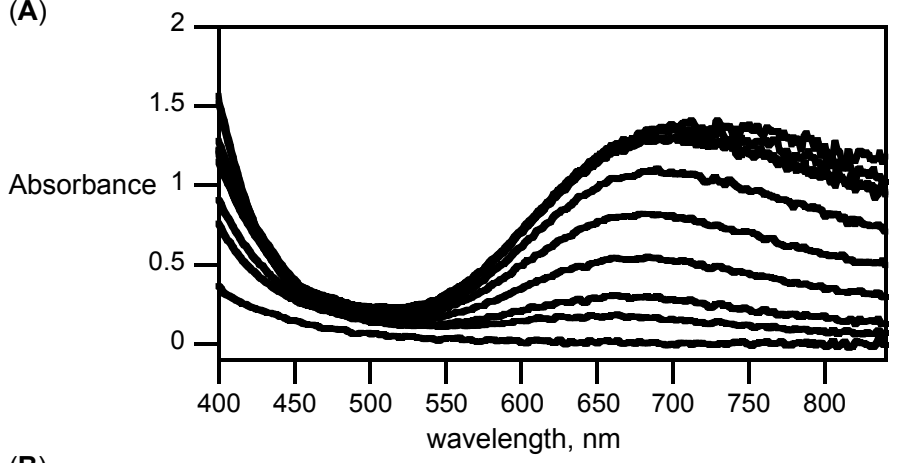

(B)

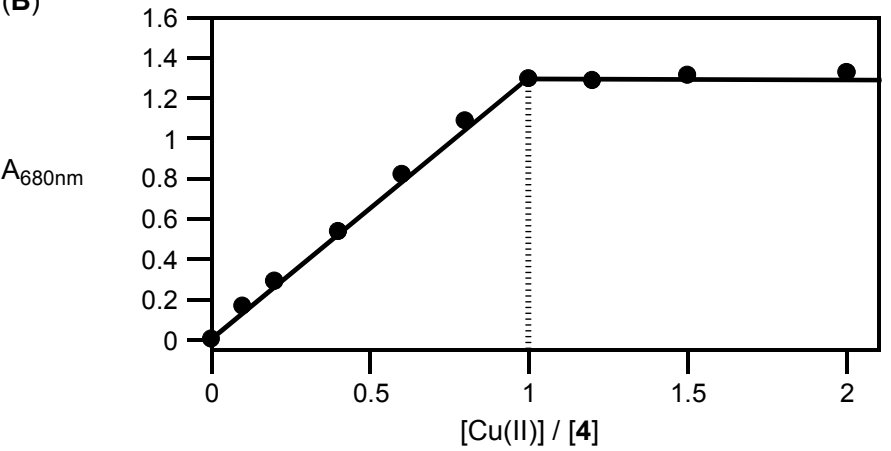

Figure 4. Measurement of the stoichiometry of affinity ligand $4(100 \mathrm{mM})$ binding to $\mathrm{Cu}(\mathrm{OTf})_{2}(0,10$, $20,40,60,80,100,120,150,200 \mathrm{mM})$ in DMSO/ $\mathrm{H}_{2} \mathrm{O}(5: 1, v / v)$ solution. (A) UV-vis spectra (1 mm path length) of samples with various $(\mathrm{Cu}(\mathrm{II})) /(4)$ molar ratios were scanned, collected and overlapped by a NanoDrop 2000 spectrophotometer; (B) A plot of $\lambda_{\max }$ absorbance at $680 \mathrm{~nm}$ vs. $(\mathrm{Cu}(\mathrm{II})) /(4)$ was used to determine the binding stoichiometry of 4 with $\mathrm{Cu}(\mathrm{OTf})_{2}$.

Figure 5 demonstrates that a complete recovery of $\mathrm{Cu}$ (II) ion from ionic liquid phase into the aqueous layer could be readily achieved by diminishing AIL 3 binding with $\mathrm{Cu}$ (II) using a high concentration ( $1 \mathrm{M})$ of $\mathrm{HCl}$. Thus, AIL 3 in ionic liquid 2 could be readily regenerated.

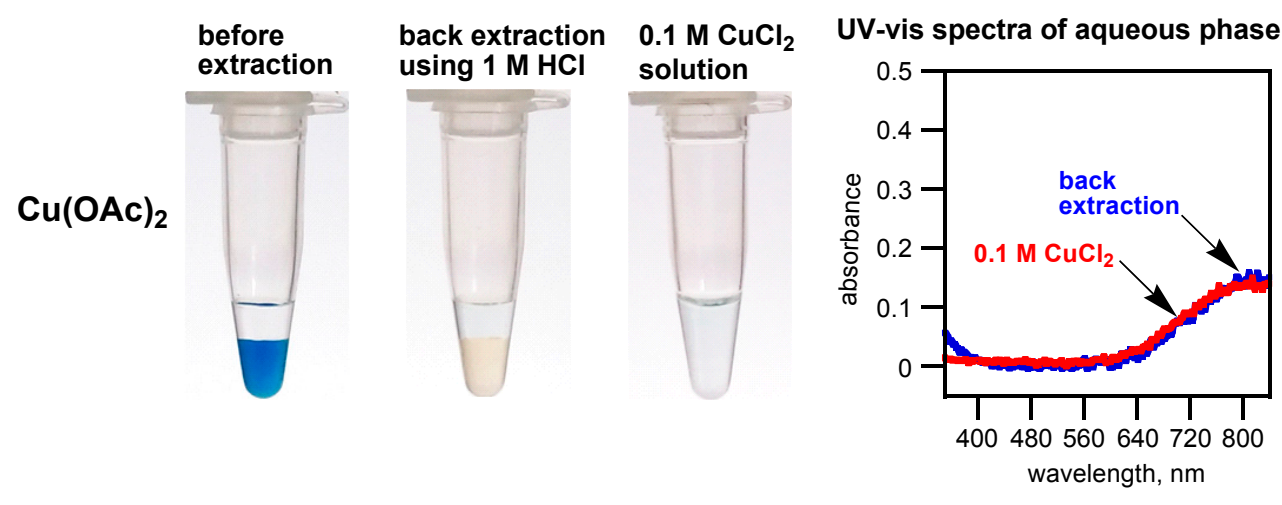

Figure 5. Optical photographic images and UV-vis spectra of competitive extraction of $\mathrm{Cu}(\mathrm{OAc})_{2}$ $(0.1 \mathrm{M})$ and AIL $3(0.25 \mathrm{M})$ in ionic liquid $2(25 \mu \mathrm{L})$ by $1 \mathrm{M} \mathrm{HCl}$ in $\mathrm{H}_{2} \mathrm{O}(25 \mu \mathrm{L})$. A photograph of $0.1 \mathrm{M}$ $\mathrm{CuCl}_{2}$ aqueous solution $(50 \mu \mathrm{L})$ was also included for comparison.

Since $\mathrm{Cu}(\mathrm{II})$-iminodiacetic acid and related structural motifs are known for their abilities to bind to histidine residues in peptides and proteins [38-40,43], we envisaged that our AIL 3-Cu(II) complex system should be an effective platform for the one-step affinity isolation and purification of His-containing peptides by AIL 3. Preliminary results of affinity extraction of $\mathrm{Cu}(\mathrm{II})$-chelated AIL 3 with a dabsylated Dab-RHHHH-NH 2 pentapeptide amide shown in Figure 6 clearly indicated 
that AIL 3-Cu(II) complex in ionic liquid 1 quantitatively extracted the peptide from aqueous phase into the bottom ionic liquid layer. Only with AIL 3 in ionic liquid 1, Dab-RHHHH-NH${ }_{2}$ peptide remained totally unaffected in the upper water layer upon extraction. Furthermore, this peptide could be conveniently and completely recovered by $1 \mathrm{M} \mathrm{HCl}$ (Figure 6).

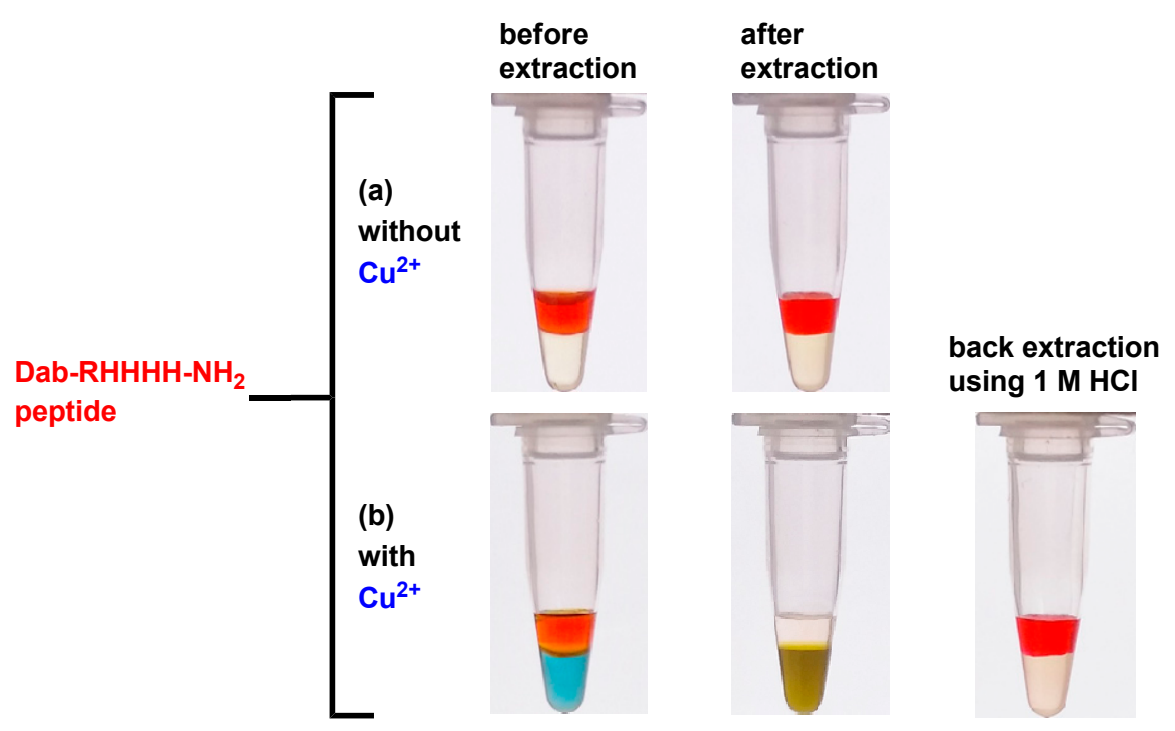

Figure 6. Affinity extraction of the dabsylated His-containing pentapeptide amide Dab-RHHHH-NH $(1 \mathrm{mM}$ ) in $200 \mathrm{mM} \mathrm{NaOAc}$ buffer (pH 4.4) containing 10\% DMSO (upper layer, $25 \mu \mathrm{L}$ ) by AIL 3 $(100 \mathrm{mM})$ solubilized in ionic liquid $\mathbf{1}$ (bottom layer, $25 \mu \mathrm{L}) .(\mathbf{a}, \mathbf{b})$ are optical photographic images of peptide extraction into ionic liquid layer without and with chelated $\mathrm{Cu}^{2+}(50 \mathrm{mM})$, respectively. Back extraction of the peptide in ionic liquid layer into aqueous layer could be conveniently achieved using $1 \mathrm{M} \mathrm{HCl}$ solution (upper layer, $25 \mu \mathrm{L}$ ).

\section{Materials and Methods}

\subsection{General Information}

The ${ }^{1} \mathrm{H}-\mathrm{NMR}$ and ${ }^{13} \mathrm{C}-\mathrm{NMR}$ spectra were recorded at $400 \mathrm{MHz}$ and $100 \mathrm{MHz}$, respectively on an Avance DPX 400 spectrometer (Bruker, Billerica, MA, USA) in deuterated solvents $\left(\mathrm{CDCl}_{3}\right.$ or DMSO- $d_{6}$ ) using TMS as the internal standard. The chemical shift $(\delta)$ for ${ }^{1} \mathrm{H}$ and ${ }^{13} \mathrm{C}$ are given in ppm relative to residual signal of the solvent. Coupling constants are given in Hz. The following abbreviations are used to indicate the multiplicity: s, singlet; $d$, doublet; $t$, triplet; $q$, quartet; $m$, multiplet; dd, doublet of doublets; td, triplet of doublets; dt, doublet of triplets; ddd, doublet of doublet of doublets; brs, broad signal. Microwave irradiation experiments were performed using a CEM Discover microwave reactor from CEM Corporation (Matthews, NC, USA). The reactions were monitored using TLC silica gel 60 F254 (Merck, Darmstadt, Germany). Evaporation of solvents was performed under reduced pressure. Melting points were measured and recorded by the OptiMelt MPA-100 apparatus (Standford Research Systems, Sunnyvale, CA, USA) and uncorrected. All starting materials, reagents and solvents were purchased from commercial sources and used as such without further purification. Unless otherwise stated, all reactions were carried out under inert atmosphere using anhydrous solvents.

\subsection{Synthesis of 4,5,6,7-Tetrahydro[1,2,3]triazolo[1,5-a]pyridine}

To a ice chilled solution of 5-hexyn-1-ol $(4.77 \mathrm{~g}, 48.57 \mathrm{mmol})$ and triethylamine $(13.6 \mathrm{~mL}$, $97.14 \mathrm{mmol})$ in dichloromethane $(80 \mathrm{~mL})$ was slowly added solution of methanesulfonyl chloride $(6.68 \mathrm{~g}, 58.28 \mathrm{mmol})$ in dichloromethane $(40 \mathrm{~mL})$. The resulting solution was aged first for $30 \mathrm{~min}$ in ice bath and then brought to ambient temperature for another $2 \mathrm{~h}$. The reaction solution was washed 
sequentially with citric acid $(10 \mathrm{wt} \%, 3 \times 15 \mathrm{~mL})$, sodium bicarbonate $(10 \mathrm{wt} \%, 3 \times 15 \mathrm{~mL})$, then dried over $\mathrm{Na}_{2} \mathrm{SO}_{4}$. After filtration, the solvent was removed under reduced pressure to afford high purity product ( $8.47 \mathrm{~g}$, quantitative yield) with no need for further purification.

The obtained sulfonate $(8.47 \mathrm{~g}, 48.05 \mathrm{mmol})$ was dissolved in DMF $(40 \mathrm{~mL})$ and then sodium azide $(6.25 \mathrm{~g}, 96.10 \mathrm{mmol})$ was added. The substitution reaction was carried out at ambient temperature for $8 \mathrm{~h}$. The resulting solution was then diluted with toluene $(962 \mathrm{~mL})$ and refluxed for $6 \mathrm{~h}$. After completion of reaction, solvents were removed in vacuo. Dichloromethane $(100 \mathrm{~mL})$ was added and the resulting solution was washed with water $(4 \times 20 \mathrm{~mL})$. Organic layers was dried over $\mathrm{Na}_{2} \mathrm{SO}_{4}$, filtered and concentrated under reduced pressure to afford high purity product 4,5,6,7-tetrahydro-[1,2,3]triazolo[1,5-a]pyridine as a light brown liquid (5.77 g, 98\% yield) with no need for further purification. ${ }^{1} \mathrm{H}-\mathrm{NMR}\left(\mathrm{CDCl}_{3}\right) \delta 1.86-1.97\left(\mathrm{~m}, 2 \mathrm{H}, \mathrm{CH}_{2}\right), 2.02-2.14\left(\mathrm{~m}, 2 \mathrm{H}, \mathrm{CH}_{2}\right), 2.84$ $\left(\mathrm{t}, J=6.4 \mathrm{~Hz}, 2 \mathrm{H}, \mathrm{CH}_{2} \mathrm{C}=\mathrm{C}\right), 4.37\left(\mathrm{t}, J=6.2 \mathrm{~Hz}, 2 \mathrm{H}, \mathrm{NCH}_{2}\right), 7.44(\mathrm{~s}, 1 \mathrm{H}, \operatorname{aryl~H}) ;{ }^{13} \mathrm{C}-\mathrm{NMR}\left(\mathrm{DMSO}-d_{6}\right)$ $\delta 19.80,19.82,22.4,45.7,130.3,133.0$.

\subsection{Synthesis of Ionic Liquid [b-4C-tr][NTf 2$]$ (1)}

Solution of methanesulfonyl chloride $(5.23 \mathrm{~g}, 45.66 \mathrm{mmol})$ in dichloromethane $(55 \mathrm{~mL})$ was slowly added to the ice bathed solution of butanol $(2.82 \mathrm{~g}, 38.05 \mathrm{mmol})$ and triethylamine $(10.6 \mathrm{~mL}$, $76.10 \mathrm{mmol})$ in dichloromethane $(55 \mathrm{~mL})$. The resulting solution was allowed to react in an ice bath for $30 \mathrm{~min}$ and then brought to ambient temperature for another $2 \mathrm{~h}$. Sequentially, the reaction solution was washed with citric acid $(10 \mathrm{wt} \%, 3 \times 15 \mathrm{~mL})$, sodium bicarbonate $(10 \mathrm{wt} \%, 3 \times 15 \mathrm{~mL})$, then dried over $\mathrm{Na}_{2} \mathrm{SO}_{4}$. After filtration, the solvent was removed under reduced pressure to afford high purity product (5.77 g, quantitative yield) with no need for further purification. To a round bottle flask containing 4,5,6,7-tetra-hydro[1,2,3]triazolo[1,5-a]pyridine (4.13 g, $33.52 \mathrm{mmol})$ was added butyl methanesulfonate $(5.73 \mathrm{~g}, 37.64 \mathrm{mmol})$. The alkylation reaction was carried out at $80{ }^{\circ} \mathrm{C}$ for $18 \mathrm{~h}$. After completion of reaction, the mixture was allowed to cool and then ether was added to extract and wash away remaining starting reagents, if any. Ether layer $(140 \mathrm{~mL}$ in total) was removed and then the ionic liquid was concentrated under reduced pressure to afford the desired [b-4C-tr][OMs] (8.94 g, $97 \%$ yield). To the solution of [b-4C-tr][OMs] $(8.94 \mathrm{~g}, 32.45 \mathrm{mmol})$ in water $(5 \mathrm{~mL})$ was added LiNTf 2 $(10.59 \mathrm{~g}, 36.87 \mathrm{mmol})$. The metathesis reaction was allowed to proceed at ambient temperature for $13 \mathrm{~h}$. After completion of the ion exchange, the solution mixture was extracted with dichloromethane $(3 \times 5 \mathrm{~mL})$. The combined organic layers were dried over $\mathrm{Na}_{2} \mathrm{SO}_{4}$. Evaporation of the solvent in vacuo afford the ionic liquid 1, [b-4C-tr][NTf $\left.{ }_{2}\right]\left(14.54 \mathrm{~g}, 98 \%\right.$ yield). Light brown liquid; ${ }^{1} \mathrm{H}-\mathrm{NMR}\left(\mathrm{DMSO}-d_{6}\right)$ $\delta 0.91\left(\mathrm{t}, \mathrm{J}=7.4 \mathrm{~Hz}, 3 \mathrm{H}, \mathrm{CH}_{2} \mathrm{CH}_{3}\right), 1.25-1.37\left(\mathrm{~m}, 2 \mathrm{H}, \mathrm{CH}_{2} \mathrm{CH}_{3}\right), 1.81-1.93\left(\mathrm{~m}, 4 \mathrm{H}, 2 \times \mathrm{CH}_{2}\right), 2.03-2.14$ $\left(\mathrm{m}, 2 \mathrm{H}, \mathrm{CH}_{2}\right), 2.94\left(\mathrm{t}, J=6.4 \mathrm{~Hz}, 2 \mathrm{H}, \mathrm{CH}_{2} \mathrm{C}=\mathrm{C}\right), 4.51\left(\mathrm{t}, J=6.1 \mathrm{~Hz}, 2 \mathrm{H}, \mathrm{NCH}_{2}\right), 4.58(\mathrm{t}, J=7.1 \mathrm{~Hz}$, $\left.2 \mathrm{H}, \mathrm{NCH}_{2}\right), 8.68\left(\mathrm{~s}, 1 \mathrm{H}\right.$, aryl H); ${ }^{13} \mathrm{C}-\mathrm{NMR}\left(\mathrm{CDCl}_{3}\right) \delta 13.0,17.8,19.2,19.8,21.2,30.8,48.9,53.6,119.7$ $\left(q, J_{C F}=319 \mathrm{~Hz}, \mathrm{CF}_{3}\right), 127.1,140.4 ; \mathrm{FAB}-\mathrm{HRMS} m / z[\mathrm{M}]^{+}$calcd for $\mathrm{C}_{10} \mathrm{H}_{18} \mathrm{~N}_{3}$ 180.1495, found 180.1501 .

\subsection{Synthesis of Ionic Liquid [e-4C-tr][NTf $]$ (2)}

Methanesulfonyl chloride $(2.59 \mathrm{~g}, 22.62 \mathrm{mmol})$ in dichloromethane $(25 \mathrm{~mL})$ was slowly added to the ice bathed solution of ethanol $(0.87 \mathrm{~g}, 18.85 \mathrm{mmol})$ and triethylamine $(5.3 \mathrm{~mL}, 37.70 \mathrm{mmol})$ in dichloromethane $(20 \mathrm{~mL})$. The resulting solution was allowed to react in ice bath for $30 \mathrm{~min}$ and then brought to ambient temperature for another $2 \mathrm{~h}$. Sequentially, the reaction solution was washed with citric acid (10 wt \%, 3×15 mL), sodium bicarbonate $(10 \mathrm{wt} \%, 3 \times 15 \mathrm{~mL})$, then dried over $\mathrm{Na}_{2} \mathrm{SO}_{4}$. After filtration, the solvent was removed under reduced pressure to afford high purity product $(2.03 \mathrm{~g}, 87 \%$ yield) without further purification. To a round bottle flask containing 4,5,6,7-tetra-hydro[1,2,3]triazolo[1,5- $a$ ]pyridine (1.75 g, $14.23 \mathrm{mmol})$ was added ethyl methanesulfonate $\left(2.01 \mathrm{~g}, 16.2 \mathrm{mmol}, 1.14\right.$ equiv.). The alkylation reaction was performed at $73{ }^{\circ} \mathrm{C}$ for $10 \mathrm{~h}$. After completion of reaction, the reaction mixture was allowed to cool and then ether was added to extract and wash away unreacted starting reagents, if any. Organic layer ( $80 \mathrm{~mL}$ in total) was then removed and the ionic liquid phase was concentrated under reduced pressure to afford 
[e-4C-tr][OMs] (3.43 g, 98\% yield). To the solution of [e-4C-tr][OMs] (3.43 g, $13.88 \mathrm{mmol})$ in water $(2 \mathrm{~mL})$ was added $\mathrm{LiNTf}_{2}(4.38 \mathrm{~g}, 15.27 \mathrm{mmol})$. The metathesis reaction was allowed to proceed at ambient temperature for $13 \mathrm{~h}$. After completion of the ion exchange, the solution mixture was extracted with dichloromethane. The combined organic layers were dried over $\mathrm{Na}_{2} \mathrm{SO}_{4}$. Evaporation of the solvent in vacuo afford the desired ionic liquid 2, [e-4C-tr][NTf $\left.{ }_{2}\right]$ (5.79 g, 97\% yield). Light brown liquid; ${ }^{1} \mathrm{H}-\mathrm{NMR}\left(\mathrm{CDCl}_{3}\right) \delta 1.65\left(\mathrm{t}, J=7.5 \mathrm{~Hz}, 3 \mathrm{H}, \mathrm{CH}_{3}\right), 1.99-2.09\left(\mathrm{~m}, 2 \mathrm{H}, \mathrm{CH}_{2}\right), 2.18-2.29\left(\mathrm{~m}, 2 \mathrm{H}, \mathrm{CH}_{2}\right)$, $3.03\left(\mathrm{t}, J=6.4 \mathrm{~Hz}, 2 \mathrm{H}, \mathrm{CH}_{2} \mathrm{C}=\mathrm{C}\right), 4.51\left(\mathrm{t}, J=6.2 \mathrm{~Hz}, 2 \mathrm{H}, \mathrm{NCH}_{2}\right), 4.57\left(\mathrm{q}, J=7.5 \mathrm{~Hz}, 2 \mathrm{H}, \mathrm{CH}_{2} \mathrm{CH}_{3}\right), 8.19$ $(\mathrm{s}, 1 \mathrm{H}, \operatorname{aryl~H}) ;{ }^{13} \mathrm{C}-\mathrm{NMR}\left(\mathrm{CDCl}_{3}\right) \delta 13.9,17.8,19.8,21.1,48.9,49.2,119.6\left(\mathrm{q}, J_{\mathrm{CF}}=319 \mathrm{~Hz}, \mathrm{CF}_{3}\right), 126.7$, 140.4; EI-HRMS $m / z$ [M] $]^{+}$calcd for $\mathrm{C}_{8} \mathrm{H}_{14} \mathrm{~N}_{3}$ 152.1188, found 152.1183.

\subsection{One-Pot Synthesis of Tryptanthrin in [b-4C-tr][NTf $\left.f_{2}\right]$ Ionic Liquid (1)}

To a microwave reaction vessel with a magnetic stirring bar was added isatin (14.80 $\mathrm{mg}$, $0.1006 \mathrm{mmol})$, isatoic anhydride $(17.06 \mathrm{mg}, 0.1046 \mathrm{mmol})$, DIEA $(13.00 \mathrm{mg}, 0.1006 \mathrm{mmol})$ and [b-4C-tr] $\left[\mathrm{NTf}_{2}\right] \mathbf{1}(50 \mu \mathrm{L}, 2.01 \mathrm{M})$. The vessel was placed inside a CEM Discover single-mode microwave synthesizer equipped with a magnetic stirrer, where it was exposed to microwaves at $100{ }^{\circ} \mathrm{C}$ ( 30 watts) for $2 \mathrm{~min}$. The reaction mixture was cooled and then purified by flash column chromatography (ethyl acetate/hexane $=1: 5)$ to obtain tryptanthrin ( $24.9 \mathrm{mg}$, quantitative yield) as yellow crystalline solid. Yellow crystalline solid; mp 266-268 ${ }^{\circ} \mathrm{C} ;{ }^{1} \mathrm{H}-\mathrm{NMR}\left(\mathrm{CDCl}_{3}\right) \delta 7.43(\mathrm{t}, J=7.8 \mathrm{~Hz}, 1 \mathrm{H}$, aryl H), 7.67 $(\mathrm{td}, J=7.7,1.4 \mathrm{~Hz}, 1 \mathrm{H}$, aryl H), $7.78(\mathrm{td}, J=7.9,1.4 \mathrm{~Hz}, 1 \mathrm{H}$, aryl H), $7.85(\mathrm{td}, J=7.7,1.4 \mathrm{~Hz}, 1 \mathrm{H}, \operatorname{aryl~H})$, $7.91(\mathrm{dd}, J=7.0,1.4 \mathrm{~Hz}, 1 \mathrm{H}$, aryl H), $7.91(\mathrm{dd}, J=7.0,1.4 \mathrm{~Hz}, 1 \mathrm{H}$, aryl H), $8.03(\mathrm{dd}, J=8.0,1.4 \mathrm{~Hz}, 1 \mathrm{H}$, aryl $\mathrm{H}), 8.43\left(\mathrm{dd}, J=8.0,1.4 \mathrm{~Hz}, 1 \mathrm{H}\right.$, aryl H), $8.62\left(\mathrm{~d}, J=8.1 \mathrm{~Hz}, 1 \mathrm{H}\right.$, aryl H); ${ }^{13} \mathrm{C}-\mathrm{NMR}\left(\mathrm{CDCl}_{3}\right) \delta 117.9$, $121.9,123.7,125.4,127.2,127.5,130.2,130.7,135.1,138.2,144.3,146.3,146.6,158.0,182.5 ;$ EI-HRMS $m / z$ $[\mathrm{M}+\mathrm{H}]^{+}$calcd for $\mathrm{C}_{15} \mathrm{H}_{8} \mathrm{~N}_{2} \mathrm{O}_{2} 248.0586$, found 248.0586 .

\subsection{Synthesis of Affinity Ionic Liquid 3}

To a solution of hydroxylamine hydrochloride $(1.0 \mathrm{~g}, 14.4 \mathrm{mmol})$ in DMF $(2 \mathrm{~mL})$ was added 2 -vinylpyridine (2 equiv.). The resulting solution was allowed to react at ambient temperature for $24 \mathrm{~h}$. After the reaction was completed, the reaction mixture was neutralized with sodium bicarbonate $(10 \mathrm{wt} \%, 20 \mathrm{~mL})$. The product was extracted from the mixture with dichloromethane, and the resulting organic phase was dried over $\mathrm{Na}_{2} \mathrm{SO}_{4}$ and evaporated to dryness. Recrystallization of the residue from $\mathrm{CH}_{2} \mathrm{Cl}_{2} /$ hexanes yielded $\mathrm{N}, \mathrm{N}$-bis(2-(pyridin-2-yl)ethyl)hydroxylamine ( $3.10 \mathrm{~g}, 91 \%$ yield) as pale yellow solid. A mixture of $N, N$-bis(2-(pyridin-2-yl)ethyl)hydroxylamine $(1.2 \mathrm{~g}, 4.93 \mathrm{mmol})$ and zinc powder $(1.47 \mathrm{~g}, 22.4 \mathrm{~mol})$ in $2 \mathrm{~N} \mathrm{HCl}(10 \mathrm{~mL})$ was stirred at $85^{\circ} \mathrm{C}$ for $2 \mathrm{~h}$. After cooling, the solution was adjusted to $\mathrm{pH} 10$ using concentrated aqueous ammonia, and the resulting mixture extracted with $\mathrm{CH}_{2} \mathrm{Cl}_{2}$. The organic washings were dried over $\mathrm{Na}_{2} \mathrm{SO}_{4}$ and the solvent was removed under reduced pressure to afford $\mathrm{N}, \mathrm{N}$-bis(2-(pyridin-2-yl)ethyl)amine $(1.07 \mathrm{~g}, 94 \%$ yield) as a yellow oil. To a solution of 6-bromohexanoic acid $\mathrm{N}$-hydroxysuccinimide ester $(0.72 \mathrm{~g}, 2.48 \mathrm{mmol})$ in dichloromethane was added $N, N$-bis(2-(pyridin-2-yl)ethyl)amine $(2.72 \mathrm{mmol})$. The resulting solution was allowed to react at ambient temperature for $1 \mathrm{~h}$, then washed with sodium bicarbonate $(10 \mathrm{wt} \%)$, brine and finally dried over $\mathrm{Na}_{2} \mathrm{SO}_{4}$. After filtration and solvent evaporation under reduced pressure, the crude product mixture was purified by flash column chromatography using ethyl acetate as the eluent to afford the desired amide product $(0.432 \mathrm{~g}, 77 \%$ yield) as a pale yellow oil. To a round bottle containing 4,5,6,7-tetrahydro-[1,2,3]triazolo[1,5-a]pyridine $(0.77 \mathrm{~g}, 6.26 \mathrm{mmol})$ was added the above obtained amide product $(0.72 \mathrm{~g}, 1.78 \mathrm{mmol})$. The mixture was stirred at $70{ }^{\circ} \mathrm{C}$ for $24 \mathrm{~h}$. The resulting slurry was washed with ether and purified by column chromatography using methanol/dichloromethane $(1: 20, v / v)$ as the solvent to afford the desired ionic salt $(0.56 \mathrm{~g}, 59 \%$ yield). To a solution of the ionic salt (559 mg, $1.06 \mathrm{mmol})$ in dry $\mathrm{CH}_{2} \mathrm{Cl}_{2}(2 \mathrm{~mL})$ was added TMSCl (138 mg, $\left.1.27 \mathrm{mmol}\right)$ in ice bath. After $15 \mathrm{~min}, 1 \mathrm{M} \mathrm{LAH}$ in THF (5 equiv.) was added slowly to the mixture with syringe. The resulting solution was allowed to react at ambient temperature for $12 \mathrm{~h}$. After $12 \mathrm{~h}$, the solvent was removed under reduced pressure to afford solid mixture. Deionized water was added to the resulting 
mixture for quenching LAH in ice bath. After filtration, $\operatorname{LiNTf}_{2}$ (331.5 mg, $1.16 \mathrm{mmol}$ ) was added to filtrate. The reaction was allowed to proceed the ion exchange at ambient temperature for $12 \mathrm{~h}$. After completion of ion exchange, the mixture was extracted with $\mathrm{CH}_{2} \mathrm{Cl}_{2}$, the organic phases were combined and dried with $\mathrm{Na}_{2} \mathrm{SO}_{4}$. After filtration and solution concentration, the mixture purified using silica column chromatography using methanol/dichloromethane $(1: 10, v / v)$ as the solvent to give the targeted affinity ionic liquid $3\left(0.28 \mathrm{~g}, 40 \%\right.$ yield in two steps) as a yellow oil. ${ }^{1} \mathrm{H}-\mathrm{NMR}\left(\mathrm{CDCl}_{3}\right)$ $\delta$ 1.39-1.55 (m, 4H, CH $), 1.80-1.93\left(\mathrm{~m}, 2 \mathrm{H}, \mathrm{CH}_{2}\right), 1.97-2.10\left(\mathrm{~m}, 4 \mathrm{H}, \mathrm{CH}_{2}\right), 2.17-2.27\left(\mathrm{~m}, 2 \mathrm{H}, \mathrm{CH}_{2}\right)$, $3.01\left(\mathrm{t}, J=6.4 \mathrm{~Hz}, 2 \mathrm{H}, \mathrm{CH}_{2}\right), 3.21-3.30\left(\mathrm{~m}, 4 \mathrm{H}, \mathrm{CH}_{2}\right), 3.30-3.37\left(\mathrm{~m}, 2 \mathrm{H}, \mathrm{CH}_{2}\right), 3.61-3.72\left(\mathrm{~m}, 4 \mathrm{H}, \mathrm{CH}_{2}\right)$, 4.48-4.59 (m, 4H, CH 2$), 4.54\left(\mathrm{t}, J=6.2 \mathrm{~Hz}, 2 \mathrm{H}, \mathrm{CH}_{2}\right), 7.20-7.21(\mathrm{~m}, 2 \mathrm{H}$, aryl H), $7.24(\mathrm{~d}, J=8.0 \mathrm{~Hz}, 2 \mathrm{H}$, $\operatorname{aryl~H}), 7.67\left(\mathrm{td}, J=7.6,1.5 \mathrm{~Hz}, 2 \mathrm{H}\right.$, aryl H), $8.14\left(\mathrm{~d}, J=4 \mathrm{~Hz}, 2 \mathrm{H}\right.$, aryl H), $8.22(\mathrm{~s}, 1 \mathrm{H}, \operatorname{aryl~H}) ;{ }^{13} \mathrm{C}-\mathrm{NMR}$ $\left(\mathrm{CDCl}_{3}\right) \delta 17.8,19.9,21.2,22.1,25.1,25.6,28.5,29.3,48.9,51.5,52.2,53.8,119.48\left(\mathrm{q}, J_{\mathrm{CF}}=320 \mathrm{~Hz}\right.$, $\left.\mathrm{CF}_{3}\right), 122.6,123.8,127.3,137.6,140.5,148.4,156.9$; ESI-HRMS $m / z[\mathrm{M}]^{+}$calcd for $\mathrm{C}_{26} \mathrm{H}_{37} \mathrm{~N}_{6} 433.3080$, found 433.3084 .

\subsection{Synthesis of 6-Bromohexanoic Acid N-Hydroxysuccinimide Ester}

To a round bottom flask with a stir bar, 6-bromohexanoic acid (1.0 g, $5.12 \mathrm{mmol})$, $\mathrm{N}$-hydroxysuccinimide $(0.89 \mathrm{~g}, 7.69 \mathrm{mmol})$, 4-dimethylaminopyridine $(0.16 \mathrm{~g}, 1.02 \mathrm{~mol})$, and $\mathrm{CH}_{2} \mathrm{Cl}_{2}$ (12 mL) was added. The solution of 1-(3-dimethylaminopropyl)-3-ethylcarbodiimide hydrochloride $(1.18 \mathrm{~g}, 6.14 \mathrm{mmol})$ in dichloromethane $(30 \mathrm{~mL})$ added in small portions solution to the round bottle in ice bath, then the mixture was allowed to react at ambient temperature for $2 \mathrm{~h}$. When the reaction was completed, washed sequentially with citric acid (10 wt \%), sodium bicarbonate (10 wt \%) and brine. The organic washings were dried over $\mathrm{Na}_{2} \mathrm{SO}_{4}$ and the solvent was removed under reduced pressure to afford 6-bromohexanoic acid N-hydroxysuccinimide ester (1.27 g, 85\% yield) as a white solid.

\subsection{Synthesis of $N, N-B i s(2-(p y r i d i n-2-y l) e t h y l) h e x a n-1-a m i n e ~(4)$}

To a solution of $n$-hexylamine $(3.25 \mathrm{~g}, 3.21 \mathrm{mmol})$ in $\mathrm{MeOH}(2 \mathrm{~mL})$ was added 2-vinylpyridine ( 2 equiv.) and acetic acid ( 3 equiv.). The resulting solution was allowed to reflux at $65{ }^{\circ} \mathrm{C}$ for $72 \mathrm{~h}$. After the reaction was completed, the solvent and 2-vinylpyridine were removed under reduced pressure. The mixture product was adjusted to $\mathrm{pH} 10$ using concentrated aqueous $\mathrm{NaOH}(1 \mathrm{M})$, and the resulting mixture was extracted with ethyl acetate. The resulting organic phase was dried over $\mathrm{Na}_{2} \mathrm{SO}_{4}$. After filtration and solvent evaporation under reduced pressure, the crude product mixture was purified by flash column chromatography to afford affinity ligand $\mathrm{N}, \mathrm{N}$-bis(2-(pyridin-2-yl)ethyl)hexan-1-amine $\left(4,0.7534 \mathrm{~g}, 75 \%\right.$ yield) as a brown oil. ${ }^{1} \mathrm{H}-\mathrm{NMR}\left(\mathrm{CDCl}_{3}\right)$ $\delta 0.87\left(\mathrm{t}, \mathrm{CH}_{3}, 3 \mathrm{H}, J=7.0 \mathrm{~Hz}\right), 1.12-1.35\left(\mathrm{~m}, \mathrm{CH}_{2}, 6 \mathrm{H}\right), 1.35-1.49\left(\mathrm{~m}, \mathrm{CH}_{2}, 2 \mathrm{H}\right), 2.54\left(\mathrm{t}, \mathrm{CH}_{2}, 2 \mathrm{H}\right.$, $J=7.6 \mathrm{~Hz}), 2.93\left(\mathrm{bs}, \mathrm{CH}_{2}, 8 \mathrm{H}\right), 7.01-7.15(\mathrm{~m}, \operatorname{aryl~H}, 4 \mathrm{H}), 7.56(\mathrm{td}, \operatorname{aryl~H}, 2 \mathrm{H}, J=7.2,1.2 \mathrm{~Hz}), 8.52$ $(\mathrm{d}, \operatorname{aryl} \mathrm{H}, 2 \mathrm{H}, \mathrm{J}=3.2 \mathrm{~Hz}) ;{ }^{13} \mathrm{C}-\mathrm{NMR}\left(\mathrm{CDCl}_{3}\right) \delta 14.0,22.6,27.1,27.2,31.8,35.9,54.0,54.0,121.0,123.3$, 136.1, 149.1, 160.8; ESI-HRMS $m / z[\mathrm{M}+\mathrm{H}]^{+}$calcd for $\mathrm{C}_{20} \mathrm{H}_{30} \mathrm{~N}_{3} 312.2440$, found 312.2444.

\subsection{Binding Stoichiometry Measurement of $\mathrm{Cu}(\mathrm{OTf})_{2}$ with Affinity Ligand 4}

Stoichiometric titrations were performed with $200 \mathrm{mM}$ affinity ligand $4(10 \mu \mathrm{L})$ in DMSO/ $\mathrm{H}_{2} \mathrm{O}$ solution $(5: 1, v / v)$. The solution of affinity ligand 4 was titrated with an aqueous solution $(10 \mu \mathrm{L})$ containing copper triflate $(0-400 \mathrm{mM})$ in DMSO $/ \mathrm{H}_{2} \mathrm{O}$ solution $(5: 1, v / v)$. Upon mixing, the resulting solutions were analyzed by UV-Vis spectrophotometry (NanoDrop 2000, Thermo Scientific, Waltham, MA, USA). The mixture solutions exhibit a new absorption band at $\lambda=680 \mathrm{~nm}$. The absorbance $(680 \mathrm{~nm})$ of resulting solutions were plotted vs. the ratio of $(\mathrm{Cu}(\mathrm{II})) /($ affinity ligand 4$)$.

\subsection{Mass Spectrometric Analysis of Cu(II)-Affinity Ligand 4 Complex}

To a microtube with affinity ligand $4(2.7 \mathrm{mg}, 8.63 \mu \mathrm{mol})$ in methanol $(1 \mathrm{~mL})$ was added copper triflate $(3.1 \mathrm{mg}, 8.63 \mu \mathrm{mol})$. The mixture was allowed to react at ambient temperature for $10 \mathrm{~min}$, followed by washing with ether three times. The solvent of the resulting mixture was removed 
under reduced pressure to afford the $\mathrm{Cu}$ complex as brown oil. This sample was analyzed by ESI-MS ESI-HRMS $m / z[\mathrm{M}+\mathrm{Na}]^{+}$calcd for $\mathrm{C}_{22} \mathrm{H}_{29} \mathrm{~N}_{3} \mathrm{O}_{6} \mathrm{~F}_{6} \mathrm{Na}_{1} \mathrm{~S}_{2} \mathrm{Cu}_{1}$ 695.0596, found 695.0595.

\subsection{Affinity Extraction of $\mathrm{Cu}(\mathrm{OAc})_{2}$ by AIL 3 and Its Back Extraction}

To a microtube containing AIL $3(250 \mathrm{mM})$ in [e-4C-tr][NTf $\left.{ }_{2}\right]$ ionic liquid $2(25 \mu \mathrm{L})$ was added copper acetate $(100 \mathrm{mM}, 25 \mu \mathrm{L})$. The two phases were vigorously shaken to extract metal ion. The mixture was then centrifuged to induce phase separation. The upper layer was measured to determine the concentration of copper acetate remained in aqueous layer by UV-vis spectrophotometry (NanoDrop 2000). The upper aqueous layer was removed and $1 \mathrm{M} \mathrm{HCl}$ solution $(25 \mu \mathrm{L})$ was added to the tube for back extraction. The mixture solution was vigorously shaken and then centrifuged to induce phase separation. The upper layer was then measured to determine the concentration of copper chloride in the aqueous layer using the NanoDrop 2000 UV-Vis spectrophotometer.

\subsection{Affinity Extraction of Cobalt Acetate and Nickel Acetate}

To a microtube containing AIL $3(250 \mathrm{mM})$ in [e-4C-tr][NTf $f_{2}$ ionic liquid $2(25 \mu \mathrm{L})$ was added cobalt acetate or nickel acetate $(250 \mathrm{mM}, 25 \mu \mathrm{L})$. The two phases were vigorously shaken to extract metal ion. The mixture was then centrifuged to induce phase separation. The upper layer was measured to determine the concentration of cobalt acetate or nickel acetate remained in aqueous layer by UV-vis spectrophotometry (NanoDrop 2000).

\subsection{Regeneration of AIL 3}

To a microtube with $\mathrm{Cu}(\mathrm{II})$-chelated AIL 3 in ionic liquid $2(25 \mu \mathrm{L})$ was added $1 \mathrm{M} \mathrm{HCl}$ aqueous solution $(25 \mu \mathrm{L})$. This solution was vigorously shaken and then centrifuged to induce phase separation. The upper aqueous solution was removed and an aqueous solution containing $0.1 \mathrm{M} \mathrm{Li}_{2} \mathrm{CO}_{3}(100 \mu \mathrm{L})$ was added to wash the bottom ionic liquid layer five times continuously. After the final $\mathrm{Li}_{2} \mathrm{CO}_{3}$ aqueous solution was removed, the AIL 3 in ionic liquid $\mathbf{2}$ was regenerated and ready for experiments.

\subsection{Affinity Extraction of Dabsylated Pentapeptide by Cu(ll)-Chelated AIL 3 and Back Extraction}

To a microtube containing AIL $3(100 \mathrm{mM})$ in [b-4C-tr] $\left[\mathrm{NTf}_{2}\right] \mathbf{1}$ ionic liquid $(25 \mu \mathrm{L})$ was added copper acetate $(50 \mathrm{mM})$ in water $(25 \mu \mathrm{L})$. The two phase were vigorously shaken to extract metal ion, then the mixture was centrifuged to induce phase separation. After removing the upper aqueous layer, the dabsylated pentapeptide amide solution ( $1 \mathrm{mM}$ ) in $0.2 \mathrm{M} \mathrm{NaOAc}$ buffer $(\mathrm{pH} 4.4)$ containing $10 \%$ DMSO $(25 \mu \mathrm{L})$ was added to microtube. After extraction and centrifuge, the upper layers were measured to determine the concentration of dabsylated pentapeptide in aqueous layer by UV-vis spectrophotometry. The upper aqueous solution was removed and the $1 \mathrm{M} \mathrm{HCl}$ solution $(25 \mu \mathrm{L})$ was added to the microtube for back extraction. The solution was vigorously shaken and then centrifuged to induce phase separation. The upper $\mathrm{HCl}$ solution was turned red color indicating the peptide being successfully back-extracted.

\section{Conclusions}

We have developed a high yielding synthesis of bicyclic 1,2,3-triazolium ionic liquids that appear to fulfill practical requirement as solvents for chemical reactions. It is noted that this general synthesis established a common bicyclotriazole core so that derivatives of triazolium ionic liquids could be prepared, characterized and studied. Ionic liquids $\mathbf{1}$ and $\mathbf{2}$ were used to demonstrate their usefulness as ionic solvents for the synthesis of tryptanthrin and, likely, other natural and non-natural products. Lastly, an affinity ionic liquid 3 was synthesized and used to demonstrate its value in affinity extraction of both $\mathrm{Cu}$ (II) ion and His-containing peptides. Binding interaction study of AIL 3-Cu(II) complex with various biomolecules as well as experiments on reuse ability of our affinity system are actively being pursued and the result will be reported in due course. 
Supplementary Materials: Supplementary materials can be accessed at: http://www.mdpi.com/1420-3049/21/ $10 / 1355 /$ s1.

Acknowledgments: We gratefully acknowledge support of this work by grants from the Ministry of Science and Technology of Taiwan, ROC (MOST 103-2113-M-194-002-MY3). We thank Ming-Chung Tseng for useful discussion.

Author Contributions: Y.-H.C. conceived and designed the experiments; H.-Y.L. and C.-Y.C. performed the experiments; H.-T.C. performed initial experiments; Y.-H.C. analyzed the data and wrote the paper.

Conflicts of Interest: The authors declare no conflict of interest.

\section{References and Notes}

1. Tseng, M.-C.; Cheng, H.-T.; Shen, M.-J.; Chu, Y.-H. Bicyclic 1,2,3-triazolium ionic liquids: Synthesis, characterization, and application to rutaecarpine synthesis. Org. Lett. 2011, 13, 4434-4437. [CrossRef] [PubMed]

2. Schulze, B.; Schubert, U.S. Beyond click chemistry-supramolecular interactions of 1,2,3-triazoles. Chem. Soc. Rev. 2014, 43, 2522-2571. [CrossRef] [PubMed]

3. Thirumurugan, P.; Matosiuk, D.; Jozwiak, K. Click Chemistry for Drug Development and Diverse Chemical-Biology Applications. Chem. Rev. 2013, 113, 4905-4979. [CrossRef] [PubMed]

4. Smiglak, M.; Pringle, J.M.; Lu, X.; Han, L.; Zhang, S.; Gao, H.; MacFarlane, D.R.; Rogers, R.D. Ionic liquids for energy, materials, and medicine. Chem. Commun. 2014, 50, 9228-9250. [CrossRef] [PubMed]

5. Cevasco, G.; Chiappe, C. Are ionic liquids a proper solution to current environmental challenges? Green Chem. 2014, 16, 2375-2385. [CrossRef]

6. Kappe, C.O.; Pieber, B.; Dallinger, D. Microwave effects in organic synthesis: Myth or reality? Angew. Chem. Int. Ed. 2013, 52, 1088-1094. [CrossRef] [PubMed]

7. Chang, Y.-P.; Liu, W.-C.; Tseng, M.-C.; Chu, Y.-H. Ionic liquids tailored for reaction-based gas sensing on quartz crystal microbalance. Rev. Anal. Chem. 2015, 34, 77-86. [CrossRef]

8. Sowmiah, S.; Chang, C.I.; Chu, Y.-H. Ionic liquids for green organic synthesis. Curr. Org. Synth. 2012, 9, 74-95. [CrossRef]

9. Sowmiah, S.; Srinivasadesikan, V.; Tseng, M.-C.; Chu, Y.-H. On the chemical stabilities of ionic liquids. Molecules 2009, 14, 3780-3813. [CrossRef] [PubMed]

10. Li, H.-Y.; Hsu, T.-H.; Chen, C.-Y.; Tseng, M.-C.; Chu, Y.-H. Exploring silver ionic liquids for reaction-based gas sensing on quartz crystal microbalance. Analyst 2015, 140, 6245-6249. [CrossRef] [PubMed]

11. Tseng, M.-C.; Chu, Y.-H. Reaction-based azide gas sensing with tailored ionic liquids measured by quartz crystal microbalance. Anal. Chem. 2014, 86, 1949-1952. [CrossRef] [PubMed]

12. Shi, Y.; Liu, Y.-L.; Lai, P.-Y.; Tseng, M.-C.; Tseng, M.-J.; Li, Y.; Chu, Y.-H. Ionic liquids promote PCR amplification of DNA. Chem. Commun. 2012, 48, 5325-5327. [CrossRef] [PubMed]

13. Tseng, M.-C.; Tseng, M.-J.; Chu, Y.-H. Affinity ionic liquid. Chem. Commun. 2009, 7503-7505. [CrossRef] [PubMed]

14. Alonso, F.; Moglie, Y.; Radivoy, G.; Yus, M. Multicomponent synthesis of 1,2,3-triazole in water catalyzed by copper nanoparticles on activated carbon. Adv. Synth. Catal. 2010, 352, 3208-3214. [CrossRef]

15. Lau, G.P. S.; Tsao, H.N.; Zakeeruddin, S.M.; Gratzel, M.; Dyson, P.J. Highly stable dye-sensitized solar cells based on novel 1,2,3-triazolium ionic liquids. ACS Appl. Mater. Interfaces 2014, 6, 13571-13577. [CrossRef] [PubMed]

16. Based on the SciFinder search on February 14, 2016, this synthesis of tryptanthrin completed in ionic liquids has not been reported in English literature.

17. Jahng, Y. Progress in the studies on tryptanthrin, an alkaloid of history. Arch. Pharm. Res. 2013, 36, 517-535. [CrossRef] [PubMed]

18. Tucker, A.M.; Grundt, P. The chemistry of tryptanthrin and its derivatives. Arkivoc 2012, 2012, 546-569.

19. Hwang, J.-M.; Oh, T.; Kaneko, T.; Upton, A.M.; Franzblau, S.G.; Ma, Z.; Cho, S.-N.; Kim, P. Design, synthesis, and structure-activity relationship studies of tryptanthrins as antitubercular Agents. J. Nat. Prod. 2013, 76, 354-367. [CrossRef] [PubMed]

20. Danz, H.; Stoyanova, S.P.; Wippich, P.; Brattstrom, A.; Hamburger, M. Identification and isolation of the cyclooxygenase-2 inhibitory principle in Isatis tinctoria. Planta Med. 2001, 67, 411-416. [CrossRef] [PubMed] 
21. Liang, J.L.; Park, S.-E.; Kwon, Y.; Jahng, Y. Synthesis of benzo-annulated tryptanthrins and their biological properties. Bioorg. Med. Chem. 2012, 20, 4962-4967. [CrossRef] [PubMed]

22. Reddy, B.V.S.; Reddy, D.M.; Reddy, G.N.; Reddy, M.R.; Reddy, V.K. Domino oxidative cyclization of 2-aminoacetophenones for the one-pot synthesis of tryptanthrin derivatives. Eur. J. Org. Chem. 2015, 2015, 8018-8022. [CrossRef]

23. Yang, S.; Li, X.; Hu, F.; Li, Y.; Yang, Y.; Yan, J.; Kuang, C.; Yang, Q. Discovery of tryptanthrin derivatives as potent inhibitors of indoleamine 2,3-dioxygenase with therapeutic activity in Lewis lung cancer (LLC) tumor-bearing mice. J. Med. Chem. 2013, 56, 8321-8331. [CrossRef] [PubMed]

24. Gahtory, D.; Chouhan, M.; Sharma, R.; Nair, V.A. Total synthesis of a pyrroloindoloquinazoline alkaloid. Org. Lett. 2013, 15, 3942-3945. [CrossRef] [PubMed]

25. Lygin, A.V.; de Meijere, A. ortho-Lithiophenyl isocyanide: A versatile precursor for $3 H$-quinazolin-4-ones and 3H-quinazolin-4-thiones. Org. Lett. 2009, 11, 389-392. [CrossRef] [PubMed]

26. Potewar, T.M.; Ingale, S.A.; Srinivasan, K.V. Synthesis of tryptanthrin and deoxyvasicinone by a regioselective lithiation-intramolecular electrophilic reaction approach. Arkivoc 2008, 2008, 100-108.

27. Jahng, K.C.; Kim, S.I.; Kim, D.H.; Seo, C.S.; Son, J.-K.; Lee, S.H.; Lee, E.S.; Jahng, Y. One-pot synthesis of simple alkaloids: 2,3-Polymethylene-4(3H)-quinazolinones, luotonin A, tryptanthrin, and rutaecarpine. Chem. Pharm. Bull. 2008, 56, 607-609. [CrossRef] [PubMed]

28. Son, J.K.; Park, J.G.; Jahng, Y. A simple synthesis of tryptanthrin. Heterocycl. Commun. 2003, 9, 621-623. [CrossRef]

29. Sharma, V.M.; Prasanna, P.; Seshu, K.V.A.; Renuka, B.; Rao, C.V.L.; Kumar, G.S.; Narasimhulu, C.P.; Babu, P.A.; Puranik, R.C.; Subramanyam, D.; et al. Novel indolo[2,1-b]quinazoline analogues as cytostatic agents: Synthesis, biological evaluation and structure-activity relationship. Bioorg. Med. Chem. Lett. 2002, 12, 2303-2307. [CrossRef]

30. Mitscher, L.A.; Wang, W.-C.; DeMeulenaere, T.; Sulko, J.; Crake, S. Antimicrobial agents from higher plants. New synthesis and bioactivity of tryptanthrin(Indolo-[2,1-b]quinazolin-6,12-dione) and its analogues. Heterocycles 1981, 15, 1017-1021. [CrossRef]

31. Eguchi, S.; Takeuchi, H.; Matsushia, Y. Short-step synthesis of rutecarpine and tryptanthrin via intramoleculer aza-Wittig reaction. Heterocycles 1992, 33, 153-156. [CrossRef]

32. Chen, C.-W.; Tseng, M.-C.; Hsiao, S.-K.; Chen, W.-H.; Chu, Y.-H. Transimination reactions in [b-3C-im][NTf 2$]$ ionic liquid. Org. Biomol. Chem. 2011, 9, 4188-4193. [CrossRef] [PubMed]

33. Maton, C.; Vos, N.D.; Stevens, C.V. Ionic liquid thermal stabilities: Decomposition mechanisms and analysis tools. Chem. Soc. Rev. 2013, 42, 5963-5977. [CrossRef] [PubMed]

34. Stockel, J.; Safar, J.; Wallace, A.C.; Cohen, F.E.; Prusiner, S.B. Prion protein selectively binds copper(II) ions. Biochemistry 1998, 37, 7185-7193. [CrossRef] [PubMed]

35. Chang, C.J. Searching for harmony in transition-metal signaling. Nat. Chem. Biol. 2015, 11, 744-747. [CrossRef] [PubMed]

36. Aron, A.T.; Ramos-Torres, K.M.; Cotruvo, J.A., Jr.; Chang, C.J. Recognition- and reactivity-based fluorescent probes for studying transition metal signaling in living systems. Acc. Chem. Res. 2015, 48, 2434-2442. [CrossRef] [PubMed]

37. Luo, Y.; Zhang, L.; Liu, W.; Yu, Y.; Tian, Y. A single biosensor for evaluating the levels of copper ion and L-cysteine in a live rat brain with Alzheimer's disease. Angew. Chem. Int. Ed. 2015, 54, 14053-14056. [CrossRef] [PubMed]

38. Carter, K.P.; Young, A.M.; Palmer, A.E. Fluorescent sensors for measuring metal ions in living systems. Chem. Rev. 2014, 114, 4564-4601. [CrossRef] [PubMed]

39. Chen, X.; Pradhan, T.; Wang, F.; Kim, J.S.; Yoon, J. Fluorescent chemosensors based on spiroring-opening of xanthenes and related derivatives. Chem. Rev. 2012, 112, 1910-1956. [CrossRef] [PubMed]

40. Que, E.L.; Domaille, D.W.; Chang, C.J. Metals in neurobiology: Probing their chemistry and biology with molecular imaging. Chem. Rev. 2008, 108, 1517-1549. [CrossRef] [PubMed]

41. Leaver, S.A.; Palaniandavar, M.; Kilner, C.A.; Halcrow, M.A. A new synthesis of bis(2-\{pyrid-2-yl\}ethyl)amine $\left(\mathrm{L}^{\mathrm{H}}\right)$ from bis(2-\{pyrid-2-yl\}ethyl)hydroxylamine $\left(\mathrm{L}^{\mathrm{OH}}\right)$, and the copper-dependent reduction of $\mathrm{L}^{\mathrm{OH}}$ to $\mathrm{L}^{\mathrm{H}}$. Dalton Trans. 2003, 4224-4225. [CrossRef] 
42. Mass spectrometric analysis supported the proposed structure of the Cu-4 complex: ESI-HRMS $m / z$ [M $+\mathrm{Na}]^{+}$ calcd for $\mathrm{C}_{22} \mathrm{H}_{29} \mathrm{~N}_{3} \mathrm{O}_{6} \mathrm{~F}_{6} \mathrm{Na}_{1} \mathrm{~S}_{2} \mathrm{Cu}_{1}$ 695.0596, found 695.0595.

43. Kruppa, M.; Mandl, C.; Miltschitzky, S.; Konig, B. A luminescent receptor with affinity for N-terminal histidine in peptides in aqueous solution. J. Am. Chem. Soc. 2005, 127, 3362-3365. [CrossRef] [PubMed]

Sample Availability: Samples of the compounds are not available from the authors.

(C) 2016 by the authors; licensee MDPI, Basel, Switzerland. This article is an open access article distributed under the terms and conditions of the Creative Commons Attribution (CC-BY) license (http://creativecommons.org/licenses/by/4.0/). 